\title{
Variability in Carcinus maenas Fecundity Along Lagoons and Estuaries of the Portuguese Coast
}

\author{
João N. Monteiro ${ }^{1,2}$ (iD $\cdot$ Andreia Ovelheiro ${ }^{1,2} \cdot$ Ana M. Ventaneira ${ }^{2}$. Vasco Vieira ${ }^{3}$ Maria Alexandra Teodósio ${ }^{1}$ \\ Francisco Leitão ${ }^{1}$
}

Received: 13 May 2021 / Revised: 8 November 2021 / Accepted: 22 November 2021 / Published online: 6 January 2022

(c) The Author(s) 2021, corrected publication 2022

\begin{abstract}
Although Carcinus maenas as a species is widely studied, research focusing on fecundity is still scarce. The main objective of this study was to evaluate size-fecundity relationships across different lagoons and estuaries, along the Portuguese coast, to understand how the local environment affects reproductive patterns. Between 2019 and 2020, ovigerous females were collected from the Southern (Ria Formosa and Ria de Alvor), Central (Rio Sado) and Northern regions (Ria de Aveiro) of Portugal, and the fecundity of each female was estimated by counting and weighing eggs. Morphometric relationships (carapace width-egg counting; egg counting-egg weight; body wet weight-egg weight; carapace width-body wet weight) were inferred from 180 egg-bearing females with a carapace width between 26.96 and $61.25 \mathrm{~mm}$. A positive correlation between fecundity and the morphological parameters was observed. Differences in fecundity were found among all systems, from northern to southern Portugal, varying between 22121 and 408538 eggs per female. Furthermore, a regional gradient was observed across regions, with lower temperature estuaries (Ria de Aveiro) displaying an increase in fecundity. The fecundity in Rio Sado was also affected by salinity. Fecundity differences across regions were associated with hydrodynamics, temperature, and salinity differences among systems. No statistically significant differences were observed between Carapace Width—Body Wet Weight regressions performed in each studied system, indicating that, contrary to fecundity, the somatic growth of C. maenas is not affected by latitudinal or environmental conditions.
\end{abstract}

Keywords Reproductive patterns $\cdot$ Morphological parameters $\cdot$ European green crab $\cdot$ Regional differences $\cdot$ Atlantic coast

\section{Introduction}

Knowledge about breeding patterns is essential to assess stocks and the reproductive potential of marine species (Costa and Soares-Gomes 2009; Naderi et al. 2018). Fecundity is a species-specific factor that allows to evaluate the

Communicated by Paul A. Montagna

João N. Monteiro

jnmonteiro@ualg.pt

1 CCMAR- Centre of Marine Sciences, Universidade Do Algarve, Campus de Gambelas, 8005-139 Faro, Portugal

2 Universidade Do Algarve, FCT, Campus de Gambelas, 8005-139 Faro, Portugal

3 MARETEC, Instituto Superior Técnico, Universidade Técnica de Lisboa, Av. Rovisco Pais, 1049-001 Lisboa, Portugal reproductive potential and to estimate the future stock size of a given species or population (Anger and Moreira 1998; Hattori and Pinheiro 2003; Figueiredo et al. 2008). In most marine species fecundity is directly related to such biological characteristics of females as body size, maturation age, reproductive effort, and life expectancy (Pinheiro and Fransozo 1995; Llodra 2002; Pinheiro et al. 2003).

Carcinus maenas (Linnaeus 1758), the European green crab, is a widely distributed epibenthic species inhabiting both hard and soft intertidal habitats in coasts and estuaries (Baeta et al. 2005). Worldwide, it is one of the most ecologically prominent benthic predators in marine and estuarine intertidal areas (Waser et al. 2017). Despite its native spatial distribution being the Northeast Atlantic, from Mauritania to Norway, and including Iceland (Crothers 1967; Carlton and Cohen 2003; Rewitz et al. 2004; Young et al. 2017), during the last two centuries this species spread its geographic distribution settling in five major regions of the globe: Northeast, Northwest and Southwest of the Pacific Ocean, and 
Northwest and Southeast Atlantic Ocean (Thresher et al. 2000; Young and Elliott 2020).

Carcinus maenas can be found along the entire Portuguese coast, presenting a high population density in the largest estuaries and lagoons from the southeast to the northwest extremes (Elumalai et al. 2007; Amaral et al. 2009; Monteiro et al. 2021). Being a key epibenthic predator that affects estuarine ecological processes via trophic interactions, $C$. maenas is of utmost ecological importance (Kristensen et al. 2008; Amaral et al. 2009; Vermeiren and Sheaves 2014). Shifts in its populations and distributions can influence estuarine communities, which may lead to major effects on the ecosystem (Grosholz and Ruiz 1995; Vermeiren and Sheaves 2014). In North America, the increase in area occupied by the invasive $C$. maenas lead to a drastic reduction in the numbers of several native benthic species, such as Mya arenaria bivalve (Cohen et al. 1995) and American oysters (Crassostrea virginica) (Pickering et al. 2017), leading to potentially large economic losses (Leignel et al. 2014). For instance, in the Gulf of St. Lawrence the estimated economic losses in bivalve fisheries and aquaculture, due to C. maenas, varied between 42 and 109 million dollars (Colautti et al. 2006). Nowadays, these losses may persist, as C. maenas eradication effort was unsuccessful (Young and Elliott 2020). Still, the fishing sector adapted to the new reality by targeting C. maenas. Aside from its deleterious effect on other fisheries, C. maenas is also of high economic importance as harvested species, mainly in Europe. According to port landing data provided by the "Directorate-general for natural resources, safety and maritime services" (DGRM), this crab is fished along the entire Portuguese coast. C. maenas is sold as bait for octopus trap fishing, angling or sold fresh for human consumption in markets (Leitão et al. 2021). Amid the 1980s and 1990s, it was also exported to Spain, potentially for seafood broth (Gomes 1991).

In C. maenas, mating can only occur immediately after the moulting of the females while the exoskeleton is not completely calcified. In turn, males can mate with the fully consolidated exoskeleton (Crothers 1967; Reid and Naylor 1994). Males can recognize a moulting female by the pheromones released ahead of moulting (Eales 1974; Klassen and Locke 2007). The number of breeding seasons varies across different regions depending on the water temperature (Audet et al. 2008). In temperate waters there is only one reproductive period per year, whereas in warmer waters there are two (Lovell et al. 2007; Young and Elliott 2020). Along the Portuguese coast, the reproductive period occurs between October to June, when the water temperature stays below $23^{\circ} \mathrm{C}$, peaking during the cooler winter months (January and February) (Sprung 2001; Young and Elliott 2020). Temperature also affects the duration of the reproductive cycle of C. maenas, which has been observed to vary across systems (Hines et al. 2004). Therefore, regional patterns in the number of breeding periods (Young and Elliott 2020), size and number of eggs (Collin et al. 2018; Rodríguez-Félix et al. 2018), and time of the larval period (Nagaraj 1993; Spitzner et al. 2019) are found as result of environmental variability among areas.

Different populations display different conditions depending on such habitat characteristics as the physical environment or food availability (De Silva et al. 1998; Lloret et al. 2002). The quality of a given habitat has been shown to be related to marine species population conditions (De Silva et al. 1998; Lloret et al. 2002; Vieira et al. 2018), which in turn can be assessed by a variety of criteria ranging from morphometric and physiological measures to biochemical measures (Lloret et al. 2002; Vieira et al. 2018; Creed et al. 2019). Weight-length relationship data is routinely collected for marine species. This information has been used as an indicator of the environmental quality of marine habitats (Jisr et al. 2018) and used to determine body condition indices providing measures of relative assemblage integrity (Jisr et al. 2018).

Accessing reproductive parameters and the impacts upon them of environmental factors allows a better understanding of population fluctuations and fecundity. The objective of this research is to increase our understanding of environmental and regional processes affecting $C$. maenas fecundity. For that, we infer its allometry and size-fecundity relations in four lagoons and estuaries along the Portuguese coast.

\section{Materials and Methods}

\section{Study Area and Sampling Procedures}

In order to assess intra-regional differences, the study was conducted in four coastal systems with different characteristics and at different latitudes along the Portuguese coast. In southern Portugal we sampled, Ria Formosa and Ria de Alvor, on the centre, Rio Sado and in northern Portugal, Ria de Aveiro (Fig. 1). Females were collected with traps between November 2019 and February 2020, in an intermediate stage of egg mass development (orange coloration). The number of egg-bearing females caught varied between 28 individuals in Ria Formosa and 51 in Ria de Aveiro (Table 1). These sample sizes were required to obtain a large range for the ovigerous females body size.

The Ria Formosa is a highly productive shallow lagoon with a multi-inlet barrier island system that extends 55 km along south Portugal (Falcão and Vale 1990; Barbosa 2010). It is a mesotidal system with mean tidal range of approximately $2 \mathrm{~m}$, varying from $1.5 \mathrm{~m}$ to $3.5 \mathrm{~m}$, and dominated by the semi-diurnal component of the tide. Only $14 \%$ of the lagoon surface is permanently submersed (subtidal channels) and the intertidal area covers approximately $1 / 3$ 


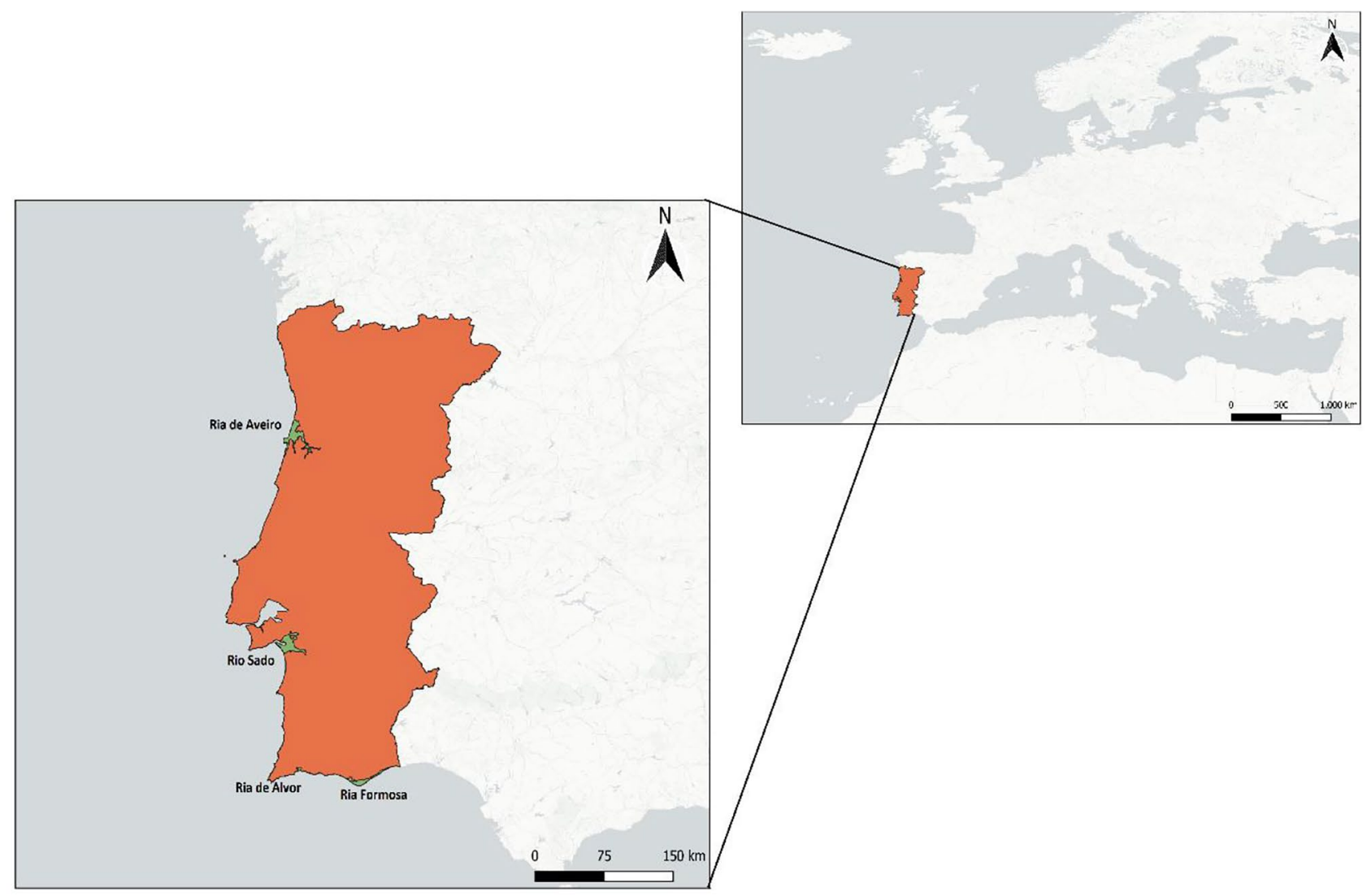

Fig. 1 Geographical location of the different systems; at orange coloration Portugal and with green coloration the areas of study: Ria Formosa, Ria de Alvor, Rio Sado and Ria de Aveiro

of the lagoon (Newton and Mudge 2003). The lagoon has an important ecological role as a breeding and nursery ground for economically valuable species (Ribeiro et al. 2008).

The Ria de Alvor is a coastal lagoon system (Duarte et al. 1999) between the cities of Lagos and Portimão that covers an area of $15 \mathrm{~km}^{2}$ (CCDRA 2004). Its tidal regime is mesotidal and semidiurnal, with an average tidal amplitude of $3.5 \mathrm{~m}$. The water temperature oscillates between $16 \mathrm{C}^{\mathrm{o}}$ in Winter and $25 \mathrm{C}^{\circ}$ in Summer. It is a system with an elevated hydrodynamics (Dias 1993) but also the most vulnerable and degraded system on the Algarve coast, because of human pressure (Duarte et al. 1999).
The Sado river estuary (hereafter named Rio Sado) is located on the western coast, being the second largest estuary in Portugal with an area of approximately $180 \mathrm{~km}^{2}$ (Ferreira et al. 2003). It is a mesotidal, well-mixed estuary (Bettencourt et al. 2004) with mean tidal range of approximately $1 \mathrm{~m}$, varying from $0.6 \mathrm{~m}$ to $1.6 \mathrm{~m}$. The exploitation of salt flats influences the water salinity inside the estuary (Gonçalves et al. 2015).

The Ria de Aveiro is a shallow coastal lagoon on the western coast of Portugal, with four main channels (LillebØ et al. 2015; Sousa et al. 2019). It is $1.3 \mathrm{~km}$ long, $350 \mathrm{~m}$ wide, $20 \mathrm{~m}$ deep (Dias and Lopes 2006). Its mesotidal regime has a tidal range between $0.6 \mathrm{~m}$ and $3.2 \mathrm{~m}$ (Dias et al. 1999).

Table 1 Biometric data and fecundity of $C$. maenas along with four different systems of the Portuguese Coast. N, number of individuals; CW, carapace width; Fecundity, number of eggs; Mean SST, mean sea surface temperature $\left({ }^{\circ} \mathrm{C}\right)$; mean salinity (PSU)

\begin{tabular}{llllllllll}
\hline System & N & Min CW & Max CW & Mean CW & Min fecundity & Max fecundity & Mean fecundity & Mean SST $\left({ }^{\circ} \mathrm{C}\right)$ & Mean salinity \\
\hline Ria Aveiro & 51 & 26.96 & 61.25 & 43.14 & 22121 & 408538 & $173751( \pm 84396)$ & 16.17 & 34.0 \\
Rio Sado & 32 & 32.63 & 51.95 & 40.64 & 31055 & 222333 & $94353( \pm 42847)$ & 17.59 & 32.0 \\
Ria Alvor & 49 & 30.82 & 56.25 & 45.18 & 28452 & 361956 & $170269( \pm 82390)$ & 18.08 & 34.0 \\
Ria Formosa & 28 & 31.96 & 55.37 & 45.68 & 61151 & 249324 & $142250( \pm 56100)$ & 19.0 & 34.7 \\
\hline
\end{tabular}




\section{Laboratory Procedures}

The carapace width (CW), carapace length (CL), and carapace thickness (CT) was measured with a $0.01 \mathrm{~mm}$ precision vernier calliper. The total weight (TW) of specimens was measured with an analytical digital scale of a $0.0001 \mathrm{~g}$ precision. Three sub-samples of the egg mass were removed from each individual (Rodríguez-Félix et al. 2018). Each replicate weight $(\mathrm{Wr})$ was measured and stored in a $4 \%$ formaldehyde solution diluted from $37 \%$ commercial formalin. The remaining egg mass was removed from the abdomen by carefully extracting the eggs from the pleopods and the females' body weight (i.e., without eggs) was taken (in g). This allowed the calculation of the total egg mass weight (Wegg). The number of eggs in each subsample (n) was placed in a Bogorov counting chamber and counted under a Leica Stereoscope.

The fecundity (F) for each subsample was estimated by the gravimetry method using Eq. 1, where $n$ is the number of eggs in the subsample, Wegg is the total egg weight, and $W \mathrm{r}$ is the weight of the subsample:

$F=\frac{n \cdot w_{e g g}}{w_{r}}$

The mean fecundity and the respective standard deviation of each egg-bearing female were calculated using the results of the three subsamples. Additionally, the minimum, maximum, and mean fecundity and respective standard deviation were calculated for each system.

The environmental data from each system, namely, annual mean temperature $\left({ }^{\circ} \mathrm{C}\right)$ and seawater salinity (PSU), were collected from Bio-ORACLE: Marine data layers for ecological modelling (https://www.bio-oracle.org/exploredata.php). Data were placed in the QGIS software and interpolated to the locations where the ovigerous females were collected.

\section{Data Analysis}

Carcinus maenas was tested for four relations among fecundity and morphometric variables: (i) egg count was regressed against $\mathrm{CW}$ by ordinary least squares (OLS); (ii) egg wet weight was regressed against egg count by principal component analysis (PCA); (iii) egg wet weight was regressed against body wet weight (i.e., weight of the body not considering the egg mass) by PCA; (iv) carapace width was tested as a predictor of its body wet weight. Because the $\mathrm{CW}$-weight relation is allometric, the predictor and response were first plotted on a log-scale and then regressed by OLS. The use of PCA or OLS depended on the proportion between the error in the measurement of $x$ and $y$ variables, and on the intention of establishing a hierarchical relation or just testing correlations (Pearson 1901; Draper 1992; Smith 2009; Vieira et al. 2016). A probability level $\alpha<0.05$ was used in all analyses in order to reject the null hypothesis.

\section{ANCOVA}

The four abovementioned relations were further tested for the extra effect of the covariate "system" and hence, compared among four estuarine and lagoon systems in PortugalRia Formosa, Ria de Alvor, Rio Sado and Ria de Aveiroapplying an analysis of covariance (ANCOVA). These models take the form $y=a+\beta x+a x+\varepsilon$. Here, the response variable $(y)$ was fecundity and the predictor $(x)$ was a morphometric measure. The covariate $(a)$ was "systems" with four levels corresponding to Ria Formosa, Ria de Alvor, Rio Sado and Ria de Aveiro. The covariate $(a)$ is also known as the categorical independent variable. The error term $(\varepsilon)$ within each system should tend to 0 and be similar among systems. The first step was to test that independent variables (predictor and covariate) were uncorrelated $(\mathrm{ax} \approx 0)$ and that there was indeed a response to a predictor-i.e., that there was a true $x y$ correlation leading to a $\beta$ significantly different from 0 . Only in such case we proceeded to the second step, where it was tested whether systems had homogeneity of slopes. If (when) they did, we proceeded to the third and final step, where a pooled slope was applied to the systems to test the differences among intercepts i.e., among the levels of each system. This protocol was followed with the significances of slopes and pairwise differences between slopes and between intercepts being estimated by permutation tests with 1000 randomizations using the software by Vieira and Creed (2013a, b). The logarithm of CL and the logarithm of body wet weight (BWW) were regressed on each other using PCA. This is justified by (i) the absence of a hierarchical relation between variables, (ii) both variables measured with similar accuracy, and (iii) both variables have similar variances (Draper 1992; Smith 2009; Vieira et al. 2016). The EC was regressed on CW using OLS. The egg count (EC) was regressed on egg weight (EW) using OLS. The EW was regressed on BWW using OLS, yielding results identically to the application of PCA.

\section{Results}

The CW of the 180 egg-bearing females varied between 26.96 and $61.25 \mathrm{~mm}$, and the fecundity varied between 22121 and 408538 eggs/female (Table 1). All the extreme values were obtained from Ria de Aveiro, where, from the 51 females, the CW varied between 26.96 and $61.25 \mathrm{~mm}$ $($ mean $=43.14 \mathrm{~mm})$, whereas the fecundity varied between 22121 and 408538 (mean =173751). Among the 32 females 
sampled in Rio Sado, the CW varied between 32.63 and $51.95 \mathrm{~mm}$ (mean $=40.64 \mathrm{~mm})$, whereas the fecundity varied between 31055 and 222333 eggs/female (mean =94353). Among the 49 females sampled in the Ria de Alvor, the CW varied between 30.82 and $56.25 \mathrm{~mm}$ (mean $=45.18 \mathrm{~mm}$ ), whereas the fecundity varied between 28452 and 361956 eggs/female (mean $=170269)$. Among the 28 females sampled in the Ria Formosa, the CW varied between 31.96 and $55.37 \mathrm{~mm}($ mean $=45.68 \mathrm{~mm})$, whereas the fecundity varied between 61151 and 249324 eggs/female $($ mean $=142250)$.

\section{Carapace Width-Egg Counting Relationship}

$\mathrm{CW}$ and egg counting (EC) were statistically significant correlated in all systems, with all CW-EC regressions yielding statistically significant slopes (Table 2 and Fig. 2a). Differences among slopes (EC) were observed between Ria de Alvor and both Rio Sado and Ria Formosa, but not observed for Ria de Aveiro (Table 3 and Fig. 2a). Hence, two separate groups were formed within which were tested for differences among intercepts. The first compared between Ria de Aveiro and Ria de Alvor (Table 2 and Fig. 2b), obtaining statistically significant different intercepts (Table 3). The second compared between Ria de Aveiro, Rio Sado and Ria Formosa (Table 2 and Fig. 2b), showing that intercepts were statistically significant different among all systems (Table 3). Overall, results show an isometric (linear) relation between $\mathrm{CW}$ and $\mathrm{EC}$ that changes with location. The

Table 2 Regression statistics for ANCOVA for all relations. For CW-EC relation two tests for differences among intercepts were performed: (est1) compared between Ria de Aveiro and Ria de Alvor, whereas (est2) compared among Ria de Aveiro, Rio Sado and Ria Formosa: For BWW-EW relation two tests for differences among highest fecundity was in Ria de Aveiro, then in Ria de Alvor and then, in equal terms, Rio Sado and Ria Formosa.

\section{Egg Counting and Egg Weight Relationship}

Egg counting (EC) and egg weight (EW) were statistically significant correlated in all systems, with all EC-EW regressions yielding statistically significant slopes (Table 3 and Fig. 3a). Differences among slopes (EW) were observed between Ria de Alvor and Ria de Aveiro, but not for other comparisons (Table 3 and Fig. 3a). Therefore, we tested for differences among intercepts disregarding the Ria de Alvor vs Ria de Aveiro comparison. The pooled slope of $2.49 \times 10^{-5}$ leads to significantly different intercepts (Table 2 and Fig. 3b) except between the Ria de Aveiro and Rio Sado intercepts (Table 3).

\section{Body Wet Weight-Egg Weight Relationships}

BWW and egg weight (EW) were statistically significant correlated in all systems, with all BWW-EW regressions yielding statistically significant slopes (Table 2 and Fig. 4a). Differences among slopes (EW) were observed between Ria do Alvor and both Ria Formosa and Rio Sado (Table 3 and Fig. 4a). No statistically significant differences among slopes were observed between Ria de Alvor and Ria de Aveiro or between Rio Sado and Ria Formosa. Hence, two separate groups were formed within which differences among intercepts were tested. The first compared between Ria de

\begin{tabular}{|c|c|c|c|c|c|c|c|c|c|c|}
\hline Relation & System & d.f & $\mathrm{R}$ & $\mathrm{S}$ & $\mathrm{P}$ & Int & $\mathrm{s}_{\text {est1 }}$ & int $_{\text {est1 }}$ & $\mathrm{s}_{\text {est2 }}$ & int $_{\text {est2 }}$ \\
\hline \multirow[t]{4}{*}{$\mathrm{CW} \times \mathrm{EC}$} & Ria de Aveiro & 50 & 0.617 & 9811 & $<0.001$ & $-2.47 \times 10^{-5}$ & 10308 & $-2.69 \times 10^{-5}$ & 8047 & $-1.71 \times 10^{-5}$ \\
\hline & Rio Sado & 35 & 0.446 & 7001 & $<0.001$ & $-1.95 \times 10^{-5}$ & $\longrightarrow$ & $\longrightarrow$ & 8047 & $-2.37 \times 10^{-5}$ \\
\hline & Ria de Alvor & 49 & 0.773 & 10805 & $<0.001$ & $-3.18 \times 10^{-5}$ & 10308 & $-2.96 \times 10^{-5}$ & & $\square$ \\
\hline & Ria Formosa & 27 & 0.707 & 7329 & $<0.001$ & $-1.90 \times 10^{-5}$ & 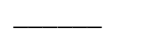 & $\longrightarrow$ & 8047 & $-2.34 \times 10^{-5}$ \\
\hline \multirow[t]{4}{*}{$\mathrm{EC} \times \mathrm{EW}$} & Ria de Aveiro & 51 & 0.757 & $2.18 \times 10^{-5}$ & $<0.001$ & 0.580 & $2.49 \times 10^{-5}$ & 0.050 & & \\
\hline & Rio Sado & 35 & 0.853 & $2.51 \times 10^{-5}$ & $<0.001$ & -0.077 & $2.49 \times 10^{-5}$ & -0.058 & & \\
\hline & Ria de Alvor & 49 & 0.907 & $2.82 \times 10^{-5}$ & $<0.001$ & 0.352 & $2.49 \times 10^{-5}$ & 0.914 & & \\
\hline & Ria Formosa & 29 & 0.748 & $2.44 \times 10^{-5}$ & $<0.001$ & 0.599 & $2.49 \times 10^{-5}$ & 0.534 & & \\
\hline \multirow[t]{4}{*}{$\mathrm{BWW} \times \mathrm{EW}$} & Ria de Aveiro & 50 & 0.740 & 0.238 & $<0.001$ & 0.317 & 0.2519 & 0.0748 & - & 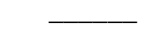 \\
\hline & Rio Sado & 32 & 0.459 & 0.162 & $<0.001$ & 0.008 & $\longrightarrow$ & 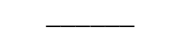 & 0.1615 & 0.0111 \\
\hline & Ria de Alvor & 48 & 0.886 & 0.266 & $<0.001$ & -0.440 & 0.2519 & -0.1154 & & \\
\hline & Ria Formosa & 29 & 0.677 & 0.162 & $<0.001$ & 0.013 & $\longrightarrow$ & & 0.1615 & 0.5075 \\
\hline \multirow[t]{4}{*}{$\mathrm{CW} \times \mathrm{BWW}$} & Ria de Aveiro & 51 & 0.970 & 2.941 & $<0.001$ & & 3.063 & -8.74 & & \\
\hline & Rio Sado & 35 & 0.948 & 3.182 & $<0.001$ & & 3.063 & -8.74 & & \\
\hline & Ria de Alvor & 49 & 0.966 & 3.045 & $<0.001$ & & 3.063 & -8.71 & & \\
\hline & Ria Formosa & 29 & 0.971 & 3.085 & $<0.001$ & $\longrightarrow$ & 3.063 & -8.73 & & $\bar{\square}$ \\
\hline
\end{tabular}

intercepts were performed: (est1) compared between Ria de Aveiro and Ria de Alvor, whereas (est2) compared between Rio Sado and Ria Formosa. CW, carapace width; EC, egg counting, EW, egg weight; BWW, body wet weight; d.f., degrees of freedom; r, correlation coefficient; S, slopes; $p$, statistical value; Int, intercept 


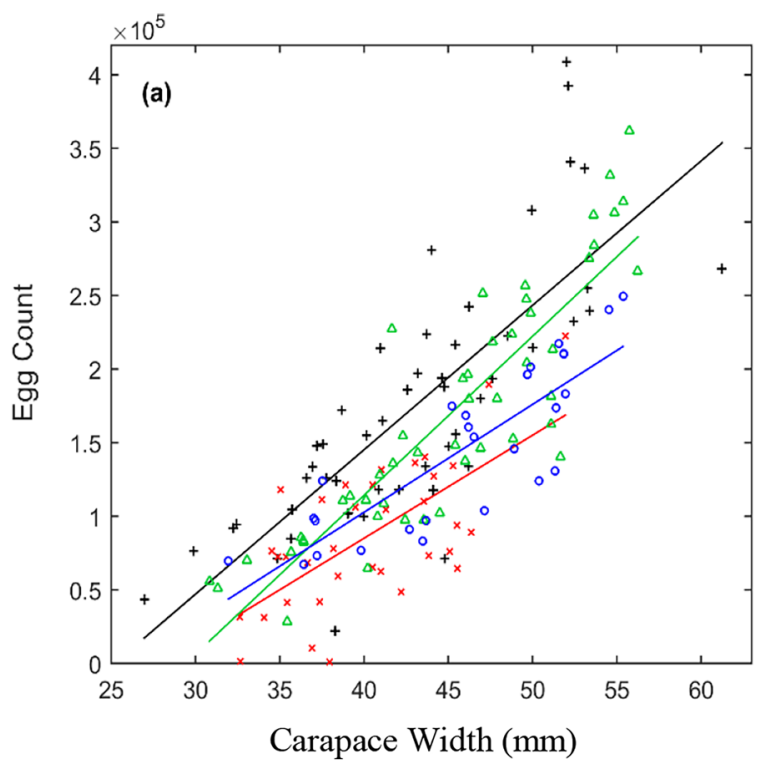

Fig. 2 Carcinus maenas egg count regressed against carapace width and compared among four lagoon and estuarine systems from Portugal. The ANCOVA protocol tested for a differences among slopes, and then for $\mathbf{b}$ differences among intercepts. Two tests for differences

Aveiro and Ria de Alvor (Table 2 and Fig. 4b), not revealing significant differences (Table 3). The second compared between Rio Sado and Ria Formosa, obtaining significantly different intercepts (Tables 2 and 3 and Fig. 4b). Results

Table 3 ANCOVA's comparing each regression among four systems. Values are the significances of pair-wise differences between systems. The upper triangle has results for slopes and the lower triangle has results for intercepts. For CW-EC relation two tests for differences among intercepts were performed: (est1) compared between Ria de Aveiro and Ria de Alvor, whereas (est2) compared among Ria de

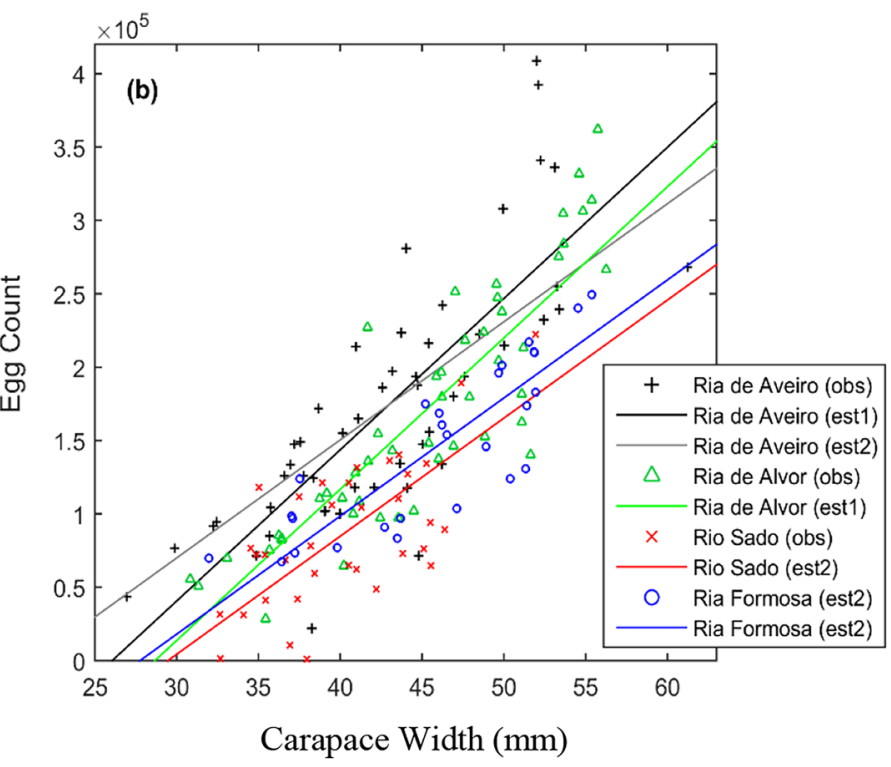

among intercepts were performed: (est1) compared between Ria de Aveiro and Ria de Alvor, whereas (est2) compared between Ria de Aveiro, Rio Sado and Ria Formosa

show an isometric (linear) relation between EW and BWW that changes with location. The highest fecundity was in the group containing Ria de Aveiro and Ria de Alvor, then, in Ria Formosa and finally in Rio Sado.

Aveiro, Rio Sado and Ria Formosa. For BWW-EW relation, two tests for differences among intercepts were performed: (est1) compared between Ria de Aveiro and Ria de Alvor, whereas (est2) compared between Rio Sado and Ria Formosa. CW, carapace width; EC, egg counting; EW, egg weight; BWW, body wet weight

\begin{tabular}{|c|c|c|c|c|c|}
\hline Relation & System & Ria de Aveiro & Rio Sado & Ria de Alvor & Ria Formosa \\
\hline \multirow[t]{4}{*}{$\mathrm{CW} \times \mathrm{EC}$} & Ria de Aveiro & $\longrightarrow$ & 0.176 & 0.542 & 0.205 \\
\hline & Rio Sado & $<0.001$ (est2) & $\longrightarrow$ & 0.010 & 0.818 \\
\hline & Ria de Alvor & 0.005 (est1) & - & - & 0.017 \\
\hline & Ria Formosa & $<0.001$ (est2) & 0.0132 (est2) & - & $\longrightarrow$ \\
\hline \multirow[t]{4}{*}{$\mathrm{EC} \times \mathrm{EW}$} & Ria de Aveiro & $\longrightarrow$ & 0.263 & 0.006 & 0.396 \\
\hline & Rio Sado & 0.588 & $\longrightarrow$ & 0.194 & 0.879 \\
\hline & Ria de Alvor & $<0.001$ & $<0.001$ & $\longrightarrow$ & 0.150 \\
\hline & Ria Formosa & 0.034 & 0.001 & 0.046 & $\longrightarrow$ \\
\hline \multirow[t]{4}{*}{$\mathrm{BWW} \times \mathrm{EW}$} & Ria de Aveiro & $\longrightarrow$ & 0.113 & 0.526 & 0.044 \\
\hline & Rio Sado & & $\longrightarrow$ & $<0.001$ & 0.992 \\
\hline & Ria de Alvor & 0.247 (est1) & - & $\longrightarrow$ & $<0.001$ \\
\hline & Ria Formosa & & 0.046 (est2) & - & $\longrightarrow$ \\
\hline \multirow[t]{4}{*}{$\mathrm{CW} \times \mathrm{BWW}$} & Ria de Aveiro & $\longrightarrow$ & 0.113 & 0.526 & 0.044 \\
\hline & Rio Sado & & $\longrightarrow$ & $<0.001$ & 0.992 \\
\hline & Ria de Alvor & 0.247 (est1) & - & - & $<0.001$ \\
\hline & Ria Formosa & & 0.046 (est2) & - & 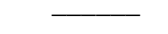 \\
\hline
\end{tabular}



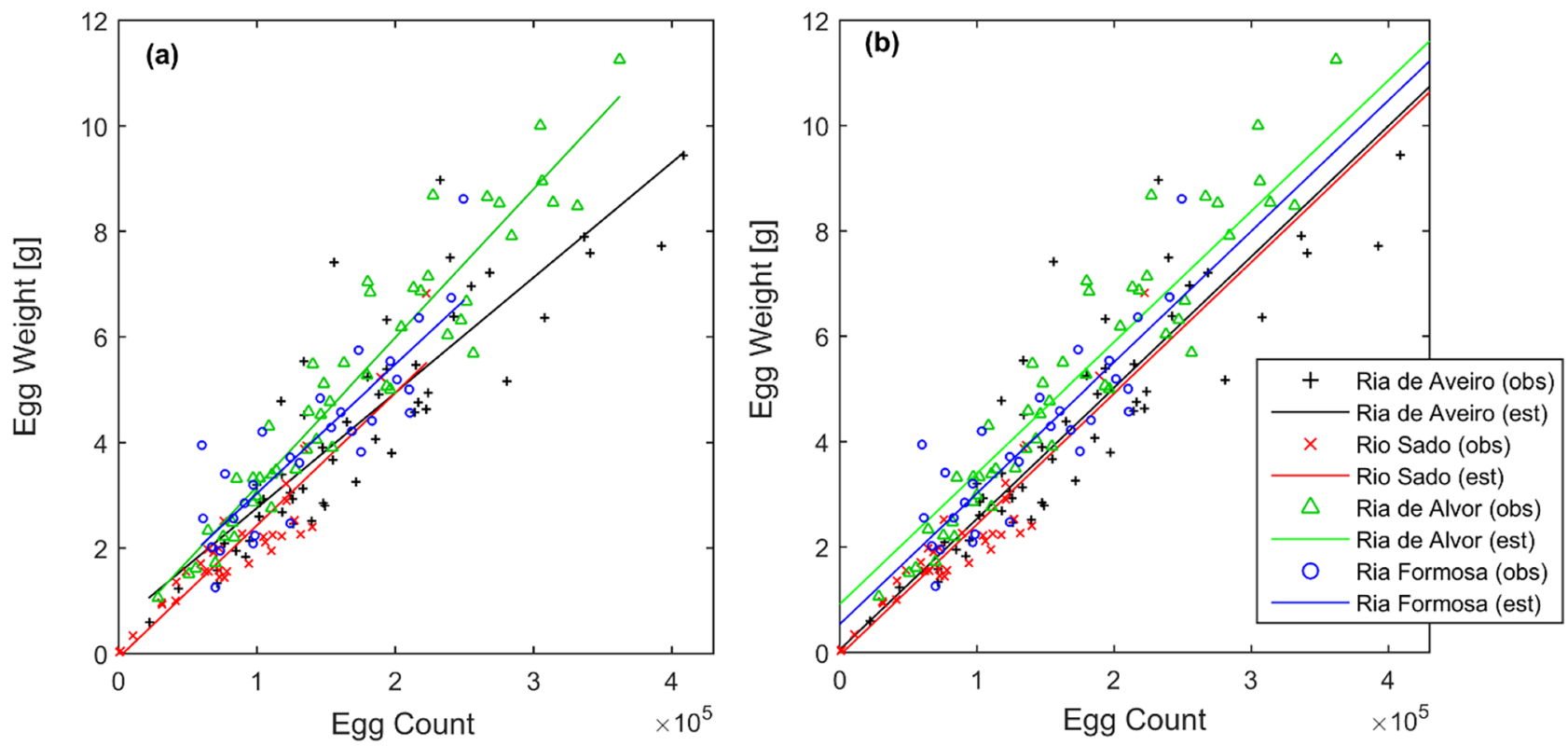

Fig. 3 Carcinus maenas egg weight regressed against egg count and compared among four lagoon and estuarine systems from Portugal. The ANCOVA protocol tested for (a) differences among slopes, and then for (b) differences among intercepts

\section{Carapace Width and Body Wet Weight Relationship}

$\mathrm{CW}$ and BWW were statistically significant correlated in all systems, with all CW-BWW logarithm regressions yielding statistically significant slopes (Table 2 and Fig. 5a). However, no statistical differences among slopes were observed (Table 3 and Fig. 5a). Hence, a pooled slope of 3.0632 was applied and then tested for differences among intercepts. No statistical differences among intercepts were observed (Table 2 and Fig. 5b). These results prove that the allometric relation between $\mathrm{CW}$ and BWW follows the exponential form $\mathrm{BWW}=1.62 \times 10^{-4} \times \mathrm{CW}^{3.0632}$ for the four systems tested. The exponent $\approx 3$ indicates that growth is nearly isometric, with $C$. maenas females preserving its shape throughout their lives.

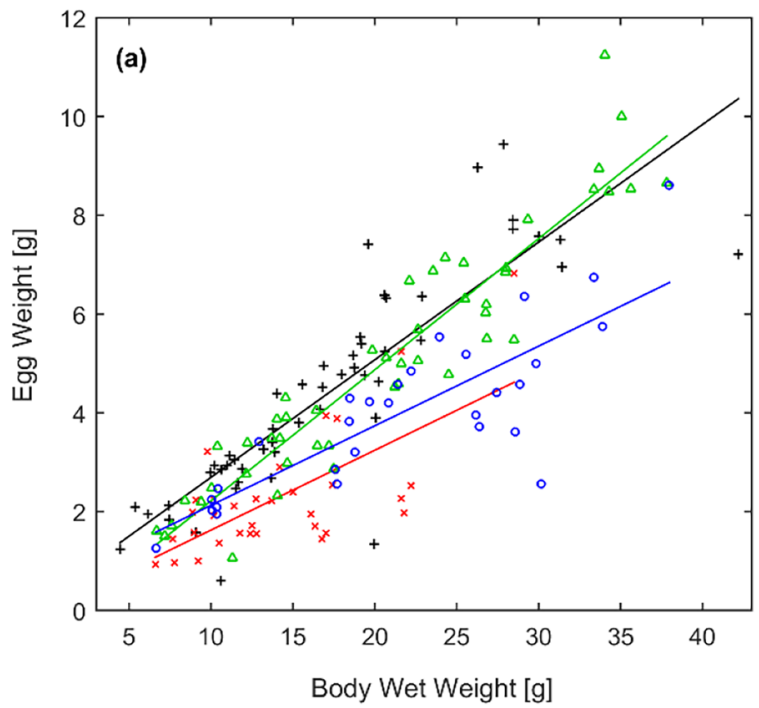

Fig. 4 Carcinus maenas egg weight regressed against body wet weight and compared among four lagoon and estuarine systems from Portugal. The ANCOVA protocol tested for (a) differences among slopes, and then for (b) differences among intercepts. Two tests for

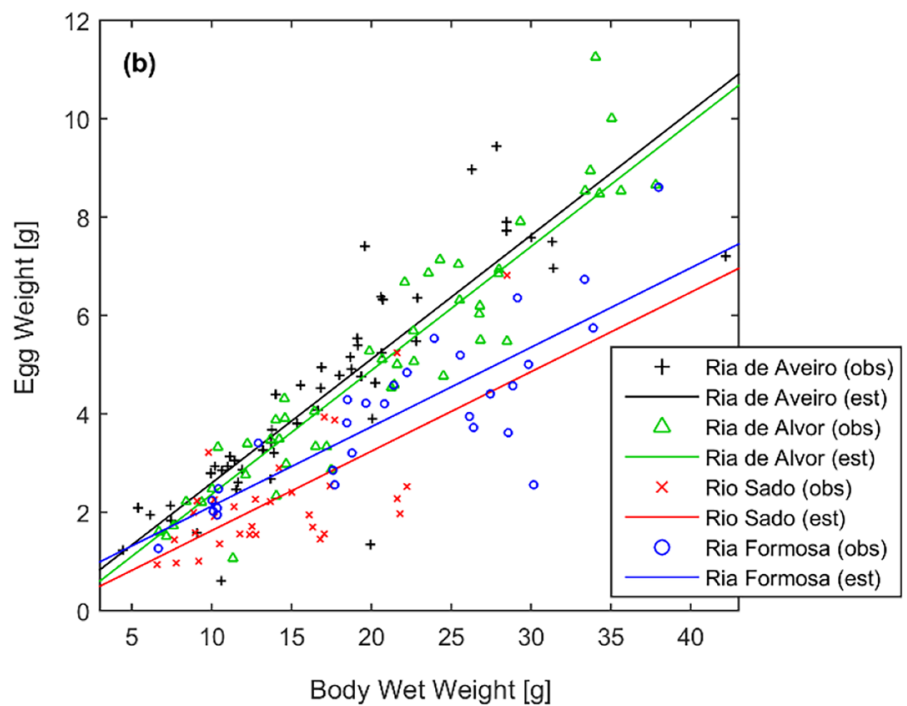

differences among intercepts were performed: (est1) compared between Ria de Aveiro and Ria de Alvor, whereas (est2) compared between Rio Sado and Ria Formosa 

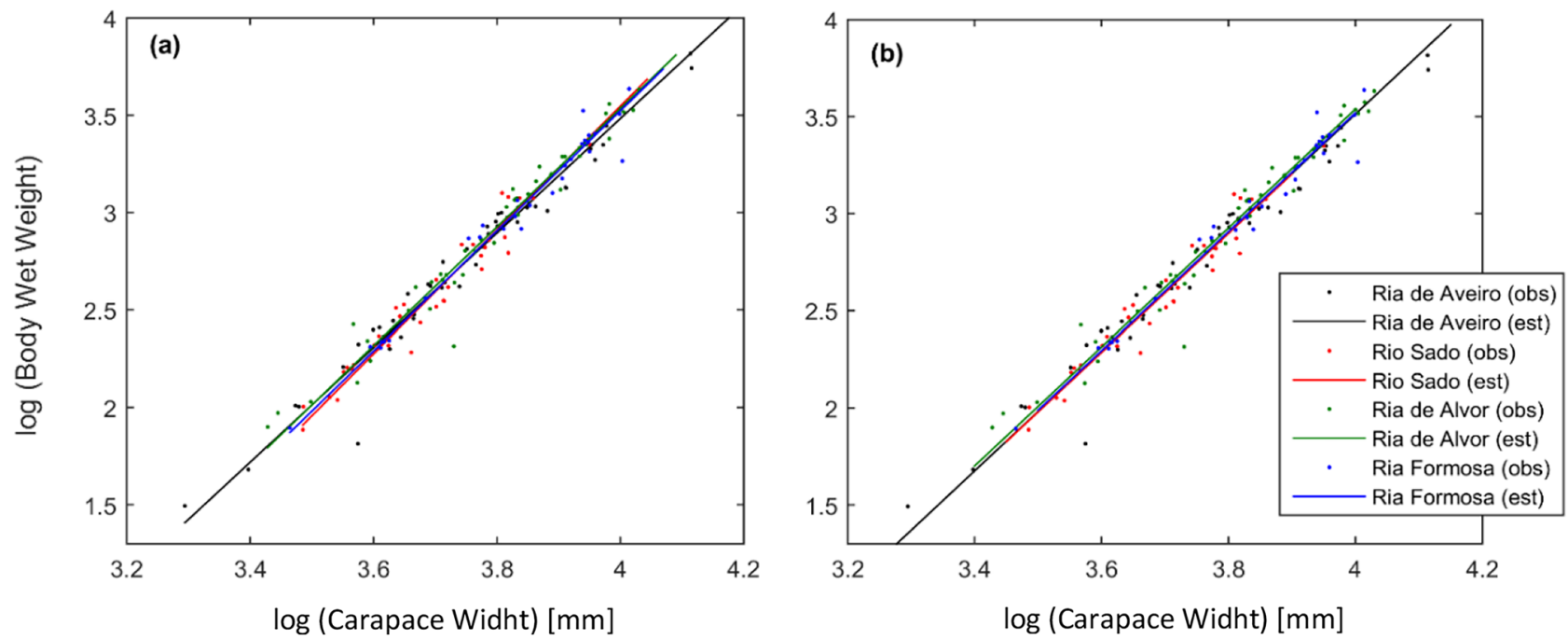

Fig. 5 Carcinus maenas body wet weight regressed against carapace width and compared among four lagoon and estuarine systems from Portugal. The ANCOVA protocol tested for (a) differences among slopes, and then for (b) differences among intercepts

\section{Discussion}

The present work provided new information on the reproductive biology of $C$. maenas along the North-western Atlantic coast, uncovering important knowledge about a fecundity gradient across the Portuguese coast. Classified as one of the world's 100 worst invaders by the International Union for Conservation of Nature (IUCN) (Lowe et al. 2000), C. maenas is the world's most widely distributed intertidal crab, with several articles on its ecology and larval development (Young and Elliott 2020). Despite the large existing scientific knowledge on C. maenas, data on fecundity and breeding patterns of this species are still scarce, being restricted to two studies on non-native populations from the Northeast coast of North America (Audet et al. 2008; Griffen 2013).

The positive correlation between morphological parameters and fecundity ( $\mathrm{CW}$ vs EC and BWW vs EW) shows that fecundity is proportional to body size, regardless of the systems. This relationship is explained by the abdomen carapace width: the larger the abdomen $(\mathrm{CW})$ the higher the number of eggs a female (higher fecundity) can bear (Audet et al. 2008; Rodríguez-Félix et al. 2018). Our results are in line with other studies on marine species where an increase in the female body size also lead to an increase in their fecundity. Such were the cases for non-native populations of C. maenas (Audet et al. 2008; Griffen 2013), congeneric species Carcinus aestuarii (Baklouti et al. 2013) and other species of crabs (Rodríguez-Félix et al. 2018) and fishes (Quinn et al. 2011).

Several fecundity studies on Carcinus genus (C. maenas and $C$. aestuarii a congeneric species) showed that fecundity varies widely across regions (Table 4). The results obtained in our study are in line with the fecundity values recorded in non-native populations of Northeast coast of America (Audet et al. 2008; Griffen 2013). Comparing with the $C$. aestuarii populations, inhabiting in Mediterranean Sea, the fecundity calculated in our study for $C$. maenas was much higher (Table 4). The differences in fecundity within C. maenas populations or among $C$. maenas congeneric species are most likely explained by the sea surface difference across areas, for instance higher temperatures in the Mediterranean Sea are associated to low crabs' fecundity (Table 4).

However, this study confirmed the existence of regional differences in C. maenas fecundity associated to environmental gradients. Fecundity was higher in the systems with lower SST, which is in line with the fecundity of non-native C. maenas populations from the Northeast coast of North America (Audet et al. 2008; Griffen 2013), as well as the fecundity of other marine and crab species monitored along the North-Western coast of Iberia (Perez-Miguel et al. 2020). The exception to the temperature effect is the Rio Sado, with a possible reason being the lower salinity of this system compared to the other study areas analysed (Table 1). The reproduction period in Sado occurs between the months of October and May (Sprung 2001), coinciding with the rainy periods. In the Rio Sado, this period coincides with an increase in runoff leading to a decrease in the salinity. Hence, in Rio Sado fecundity is most likely affected by the combined effect of temperature and salinity. In fact, besides temperature, other hydrological features of the study systems aspects can affect the species physiological conditions (Young and Elliott 2020), size and number of eggs (Collin et al. 2018; Rodríguez-Félix et al. 2018) and duration of the larval period (Nagaraj 1993; Spitzner et al. 2019). Therefore, differences in fecundity among systems are also associated to the 
Table 4 Mean fecundity and respective carapace width (CW) range for various populations of C. maenas and the congeneric species Carcinus aestuarii

\begin{tabular}{llllll}
\hline Species & Local & N & Range CW & Mean fecundity & Reference \\
\hline Carcinus maenas & Den Helder, Netherlands & 1 & 46 & 185000 & Broekhuysen (1936) \\
& Ria de Aveiro Lagoon, Portugal & 51 & $26.96-61.25$ & 180000 & Present study \\
& Sado estuary, Portugal & 32 & $22.51-55.05$ & 95000 & Present study \\
& Ria de Alvor Lagoon, Portugal & 49 & $25.66-56.25$ & 170000 & Present study \\
& Ria Formosa Lagoon, Portugal & 28 & $29.66-65.83$ & 140000 & Present study \\
& New Hampshire & 35 & $33.6-48.9$ & 75577 & Griffen (2013) \\
& Gulf of St. Lawerence (Canada) & 33 & $41.54-68.3$ & 195000 & Audet et al. (2008) \\
Carcinus aestuarii & Acquatina Lagoon, Italy & 12 & $23.1-41.3$ & 71101 & Lumare et al. (2009) \\
& Gulf of Gabes, Tunisia & 91 & $31.1-50.4$ & 30750 & Baklouti et al. (2013) \\
& Homa Lagoon, Turkey & 110 & $16.84-39.28$ & 42201 & Özbek et al. (2012) \\
& Lagoon of Elbibane, Tunisia & 17 & $30-45$ & 45468 & Jouili et al. (2016) \\
& Parila Lagoon, Croatia & 250 & $26-45$ & 61017 & Glamuzina et al. (2017) \\
& İzmir Bay, Turkey & 28 & $25-40$ & 42810 & Tiraşin et al. (2020) \\
\hline
\end{tabular}

particular/regional hydrology. In decapoda, the reproductive effort can be influenced by changes in environmental conditions, such as salinity (Vernberg and Piyatiratitivorakul 1998), with trade-offs between survival and reproductive activity (Gelin et al. 2001).

Morphometric relationships have been used for a local and interregional morphological comparison of populations (Froese 2006), and also to evaluate environmental ecological status (Lloret et al. 2002). Morphometric condition indices can provide information on "well-being" for some marine species (Lambert and Dutil 1997), which in turn could imply something about local ecosystem conditions, for example food limitation (Shephard et al. 2015). In our study, the positive correlation among all morphological parameters $(\mathrm{CW}, \mathrm{BWW})$ and the nearly isometric exponent $(\approx 3)$ of the $\mathrm{CW}$ vs BWW model demonstrates that females' body mainly changed in size, roughly preserving the shape. No statistically significant differences were observed among the $\mathrm{CW}$-BWW regressions performed for each studied system, indicating that, contrary to fecundity, the somatic growth of $C$. maenas is not affected by latitudinal or environmental conditions. Morphometric results on $\mathrm{CW}-\mathrm{BWW}$ regressions suggest that all the studied systems are effectively at the same environmental quality status. The study of body condition assumes that heavier individuals of a given length class are in better condition (Jones et al. 1999). Condition indices have been used in aquaculture as indicators of the general "wellbeing or fitness" of the population in consideration (Bolger and Connolly 1989). The operationalisation's level and type of the bioindicators used to assess population biological conditions, such as morphometric indicators, is shown by their inclusion, within the marine strategy framework directive in European Union (Shephard et al. 2015), where these have been proposed as environmental "surveillance indicators."

Globally, many highly prized commercial species are under assessment, and substantial data exists to predict their status (EU Reg. 1543/2000; EU reg. 665/2008). Information collected at national or international level, e.g., Data Collection Regulation (DCR) and the Data Collection Framework (DCF) programs (EU reg. 665/2008), can now make better use of this information to implement routines which aim to assess environmental quality status based on populations data. However, multiple ecosystem pressures, and cumulative or synergistic responses, can make the use of biological indicators difficult. Therefore, it is necessary to consider multiple surveillance indicators in ecosystems ecological status shifts.

Acknowledgements This study was supported by Project CRUSTAPANHA-Estudo da ecologia, biologia e dinâmica populacional dos pequenos caranguejos com interesse comercial existentes ao longo da costa Portuguesa (Operação 16-01-04-FMP-0005-CRUSTAPANHA) that is founded by Programa Operacional Mar 2020, Portugal 2020 and EU, throughout Fundo Europeu dos Assuntos Marítimos e das Pescas (FEAMP); This study received Portuguese national funds from FCT-Foundation for Science and Technology through project UID/Multi/04326/2020. Special thanks to Direção Geral dos Recursos Marinhos (DGRM) and Instituito da Conservação da Natureza e das Florestas (ICNF), which, with the issuance of the crab fishing licenses, allowed this study to be carried out. Special thanks to all fishermen who, through their aid, made it possible to collect biological samples. We thank to Eudriano Costa for useful tips regarding the gravimetry method to calculate the fecundity.

Funding Francisco Leitão received Portuguese national founds from FCT contract program DL57/2016/CP1361/CT0008. Vasco Vieira was supported by FCT/MCTES (PIDDAC) through project LARSyS-FCT Pluriannual funding 2020-2023 (UIDB/EEA/50009/2020). 
Open Access This article is licensed under a Creative Commons Attribution 4.0 International License, which permits use, sharing, adaptation, distribution and reproduction in any medium or format, as long as you give appropriate credit to the original author(s) and the source, provide a link to the Creative Commons licence, and indicate if changes were made. The images or other third party material in this article are included in the article's Creative Commons licence, unless indicated otherwise in a credit line to the material. If material is not included in the article's Creative Commons licence and your intended use is not permitted by statutory regulation or exceeds the permitted use, you will need to obtain permission directly from the copyright holder. To view a copy of this licence, visit http://creativecommons.org/licenses/by/4.0/.

\section{References}

Amaral, V., H.N. Cabral, S. Jenkins, S. Hawkins, and J. Paula. 2009. Comparing quality of estuarine and nearshore intertidal habitats for Carcinus maenas. Estuarine Coastal and Shelf Science 83 (2): 219-226.

Anger, K., and G.S. Moreira. 1998. Morphometric and reproductive traits of tropical caridean shrimps. Journal of Crustacean Biology 4: 823-838.

Audet, D., G. Miron, and M. Moriyasu. 2008. Biological characteristics of a newly established green crab (Carcinus maenas) population in the Southern Gulf of St Lawrence Canada. Journal of Shellfish Research 27: 427-441.

Baeta, A., H.N. Cabral, J.M. Neto, J.C. Marques, and M.A. Pardal. 2005. Biology, population dynamics and secondary production of the green crab Carcinus maenas (L) in a temperate estuary. Estuarine Coastal and Shelf Science 65: 43-52. https://doi.org/ 10.1016/j.ecss.2005.05.004.

Baklouti, S., A. Derbali, K. Dhieb, and O. Jarboui. 2013. Reproductive biology of the Mediterranean green crab Carcinus aestuarii Nardo 1847 (Crustacea: Portunidae) in the Gulf of Gabes (Tunisia Central Mediterranean). Cahiers De Biologie Marine 54: 411-417.

Barbosa, A. 2010. Seasonal and interannual variability of planktonic microbes in a mesotidal coastal lagoon (Ria Formosa SE Portugal): Impact of climatic changes and local-human influences. In Coastal Lagoons: Critical habitats of environmental change, ed. H. Paerl and M. Kennish, 335-366. Boca Raton: CRC Press Taylor \& Francis Group Marine Science Book Series.

Bettencourt, A., S. B. Bricker, J. G. Ferreira, A. Franco, J. C. Marques, J. J. Melo, A. Nobre, L. Ramos, C. S. Reis, F. Salas, M. C. Silva, T. Simas and W. Wolff. 2004. Typology and reference conditions for Portuguese transitional and coastal waters Development of guidelines for the application of the European Union Water Framework Directive, 98. Edição IMAR/INAG.

Bolger, T., and P.L. Connolly. 1989. The selection of suitable indices for the measurement and analysis of fish condition. Journal of Fish Biology 34 (2): 171-182. https://doi.org/10.1111/j.10958649.1989.tb03300.x.

Broekhuysen, G.J. 1936. On development, growth and distribution of Carcinides maenas (L). Archive Neerlandaise De Zoologie 2: 257-399.

Carlton, J.T., and A.N. Cohen. 2003. Episodic global dispersal in shallow water marine organisms: The case history of the European shore crabs Carcinus maenas and $C$ aestuarii. Journal of Biogeography 30: 1809-1820.

CCDRA. 2004. Recursos hídricos planeamento e gestão do recurso água - Vol II. Anexo H.

Cohen, A.N., J.T. Carlton, and M. Fountain. 1995. Introduction dispersal and potential impacts of the green crab Carcinus maenas in San Francisco Bay California. Marine Biology 122 (2): 225-237.
Colautti, R.I., S.A. Bailey, C.D.A. van Overjijk, K. Amundsen, and H.J. MacIsaac. 2006. Characterised and projected costs of nonindigenous species in Canada. Biological Invasions 8: 45-59.

Collin, R., N. Nieto, and C. Peña. 2018. Seasonal differences in egg size in three species of crabs from a tropical upwelling zone. Marine Biology Research 14 (3): 258-268. https://doi.org/10. 1080/17451000.2017.1406664.

Costa, T.M., and A. Soares-Gomes. 2009. Population structure and reproductive biology of Uca rapax (Decapoda: Ocypodidae) in a tropical coastal lagoon southeast Brazil. Zoologia 26: 647-657.

Creed, J., V.M.N.C.S. Vieira, T.A. Norton, and D. Caetano. 2019. Seaweeds surpass plants setting life-on-Earth's limit for biomass concentration. BMC Ecology 19: 6. https://doi.org/10.1186/ s12898-019-0218-z.

Crothers, J.H. 1967. The biology of the shore crab Carcinus maenas (L) I The background anatomy growth and life history. Field Studies 2 (3): 407-434.

De Silva, S.S., R.M. Gunasekera, C.M. Austin, and A. Graeme. 1998. Habitat related variations in fatty acids of catadromous Galaxias maculatus. Aquatic Living Resources 11: 379-385.

Dias, J.M., and J.F. Lopes. 2006. Implementation and assessment of hydrodynamic salt and heat transport models: The case of Ria de Aveiro lagoon (Portugal). Environmental Modelling \& Software 21: 1-15.

Dias, J.M., J. Lopes, and I. Dekeyser. 1999. Hydrological characterisation of Ria de Aveiro, Portugal, in early summer. Oceanologica Acta 22 (5): 473-485. https://doi.org/10.1016/S0399-1784(00) 87681-1.

Dias, J.M. 1993. Estudo de avaliação da situação ambiental e proposta de medidas de salvaguarda para a faixa costeira portuguesa (Geologia costeira). In Liga para a Protecção da Natureza, 10. Cap.

Draper, N.R. 1992. Straight line regression when both variables are subject to error. In Proceedings of the 1991 Kansas State university conference on applied statistics in agriculture, 1-18.

Duarte, C., A. Matias, J.A. Dias, and O. Ferreira. 1999. Vulnerabilidade dos corpos dunares do Algarve. In $10^{\circ}$ Congresso do Algarve.

Eales, A.J. 1974. Sex pheromone in the shore crab Carcinus maenas and the site of its release from females. Marine Behaviour and Physiology 2: 345-355.

Elumalai, M., C. Antunes, and L. Guilhermino. 2007. Enzymatic biomarkers in the crab Carcinus maenas from the Minho River estuary (NW Portugal) exposed to zinc and mercury. Chemosphere 66: 1249-1255.

Falcão, M., and C. Vale. 1990. Study of the Ria Formosa ecosystem: Benthic nutrient remineralization and tidal variability of nutrients in the water. Hydrobiologia 207: 137-146. https://doi.org/ 10.1007/bf00041450.

Ferreira, J.G., T. Simas, A. Nobre, M.C. Silva, K. Shifferegger, and J. Lencart-Silva. 2003. Identification of sensitive areas and vulnerable zones in transitional and coastal Portuguese systems. In Application of the United States National Estuarine Eutrophication Assessment to the Minho, Lima, Douro, Ria de Aveiro, Mondego, Tagus, Sado, Mira, Ria Formosa and Guadiana systems, 2003. INAG/IMAR.

Figueiredo, J., G. Penha-Lopes, J. Anto, L. Narciso, and J. Lin. 2008. Fecundity, brood loss and egg development through embryogenesis of Armases cinereum (Decapoda: Grapsidae). Marine Biology 154: 287-294. https://doi.org/10.1007/s00227-008-0922-2.

Froese, R. 2006. Cube law condition factor and weight-length relationships: History meta-analysis and recommendations. Journal of Applied Ichthyology 22 (4): 241-253.

Gelin, A., A.J. Crivelli, E. Rosecchi, and P. Kerambrun. 2001. Can salinity changes affect reproductive success in the brown shrimp Crangon crangon? Journal of Crustacean Biology 21 (4): 905-911. 
Glamuzina, L., A. Conides, G. Mancinelli, T. Dobroslavic, V. Bartulovic, S. Matic-Skoko, and B. Glamuzina. 2017. Population dynamics and reproduction of Mediterranean green crab Carcinus aestuarii in Parila Lagoon (Neretva Estuary Adriatic Sea Croatia) as fishery management tools. Marine and Coastal Fisheries 9: 260-270.

Gomes, V. 1991. O caranguejo Carcinus maenas (L) da Ria de Aveiro: dados sobre o valor económico, avaliação do stock e esforço de pesca. In Actas do seminário Eurocoast sobre "A zona costeira e os Problemas Ambientais", 159-166. Universidade de Aveiro.

Gonçalves, C., M.J. Brogueira, and M. Nogueira. 2015. Tidal and spatial variability of nitrous oxide (N2O) in Sado estuary (Portugal). Estuarine Coastal and Shelf Science 167: 466-474. https://doi. org/10.1016/j.ecss.2015.10.028.

Griffen, B.D. 2013. Linking individual diet variation and fecundity in an omnivorous marine consumer. Oecologia 174: 121-130.

Grosholz, E.D., and G.M. Ruiz. 1995. Spread and potential impact of the recently introduced European green crab, Carcinus maenas, in central California. Marine Biology 122 (2): 239-247. https:// doi.org/10.1007/BF00348936.

Hattori, G.Y., and M.A.A. Pinheiro. 2003. Fertilidade do caranguejode mangue Ucides cordatus (Linnaeus) (Crustacea Brachyura Ocypodidae) em Iguape (São Paulo Brasil). Revista Brasileira De Zoologia 20 (2): 309-313.

Hines, A.H., G.M. Ruiz, N.G. Hitchcock, and C. deRivera. 2004. Projecting range expansion of invasive European green crabs (Carcinus maenas) to Alaska: Temperature and salinity tolerance of larvae, 77. Environmental Science and Management Faculty Publications and Presentations.

Jisr, N., G. Younes, C. Sukhn, and M.H. El-Dakdouki. 2018. Lengthweight relationships and relative condition factor of fish inhabiting the marine area of the Eastern Mediterranean city TripoliLebanon. Egyptian Journal of Aquatic Research 44 (4): 299-305. https://doi.org/10.1016/j.ejar.2018.11.004.

Jones, R.E., R.J. Petrell, and D. Pauly. 1999. Using modified lengthweight relationships to assess the condition of fish. Aquacultural Engineering 20 (4): 261-276. https://doi.org/10.1016/S01448609(99)00020-5.

Jouili, S., M. Arculeo, L. Mansour, and L. Rabaoui. 2016. Biological characteristics of three Brachyuran crab species in the Lagoon of Elbibane South-Eastern Tunisia. Cahiers De Biologie Marine 57 (3): 217-226.

Klassen, G., and A. Locke. 2007. A biological synopsis of the European green crab Carcinus maenas, 1-75. Canadian Manuscript Report of Fisheries and Aquatic Sciences, No 2818: i-vii.

Kristensen, E., S. Bouillon, T. Dittmar, and C. Marchand. 2008. Organic carbon dynamics in mangrove ecosystems: A review. Aquatic Botany 89 (2): 201-219.

Lambert, Y., and J.D. Dutil. 1997. Condition and energy reserves of Atlantic cod (Gadus morhua) during the collapse of the northern Gulf of St Lawrence stock. Canadian Journal of Fisheries and Aquatic Sciences 54: 2388-2400.

Leignel, V., J.H. Stillman, S. Baringou, R. Thabet, and I. Metais. 2014. Overview on the European green crab Carcinus spp (Portunidae Decapoda) one of the most famous marine invaders and ecotoxicological models. Environmental Science and Pollution Research 21 (15): 9129-9144. https://doi.org/10.1007/s11356-014-2979-4.

Leitão, F., J. Bueno-Pardo, A. Ovelheiro, J.N. Monteiro, D. Nobre, and A.M. Teodósio. 2021. Effect of bait type on the octopus fishery in Algarve Southern Portugal. Ocean \& Coastal Management 207: 105587. https://doi.org/10.1016/j.ocecoaman.2021.105587.

LillebØ, A.I., P. Stalnacke, and G.D. Gooch. 2015. Coastal Lagoons in Europe: Integrated Water Resource Strategies. IWA Publishing. ISBN9781780406282.

Llodra, R.E. 2002. Fecundity and life-history strategies in marine invertebrates. Advances in Marine Biology 43: 87-170.
Lloret, J., L. Gil de Sola, A. Souplet, and R. Galzin. 2002. Effects of large-scale habitat variability on condition of demersal exploited fish in the north-western Mediterranean. ICES Journal of Marine Science 59: 1215-1227.

Lovell, S., E. Besedin, and E. Grosholz. 2007. Modeling economic impacts of the European Green Crab, 1-40. In American Agricultural Economics Association Annual Meeting.

Lowe, S., M. Browne, S. Boudjelas, and M. De Poorter. 2000. 100 of the world's worst invasive alien species: a selection from the Global Invasive Species database. Auckland: Contribution to the Global Invasive Species Programme (GISP) Published by the IUCN/SSC Invasive Species Specialist Group.

Lumare, L., D. Lumare, M. Florio, T. Scirocco, and F. Lumare. 2009. I Crostacei Decapodi del Lago di Acquatina: Struttura delle Popolazioni e Ciclo Riproduttivo. Thalassia Salentina 31: 83-102.

Monteiro, J.N., M. Pinto, D. Crespo, M.A. Pardal, and F. Martinho. 2021. Effects of climate variability on an estuarine green crab Carcinus maenas population. Marine Environmental Research 169: 105404. https://doi.org/10.1016/j.marenvres.2021.105404.

Naderi, M., S.A. Hosseini, J. Pazooki, A. Hedayati, P. Zare, and M. Lastra. 2018. Reproductive biology of the ghost crab Ocypode rotundata Miers 1882 (Decapoda Ocypodidae) at Qeshm Island Persian Gulf. Crustaceana 91 (9): 1039-1059. https://doi.org/10. 1163/15685403-00003804.

Nagaraj, M. 1993. Combined effects of temperature and salinity on the zoeal development of the green crab Carcinus maenas (Linnaeus 1758) (Decapoda: Portunidae). Scientia Marina 57 (1): 1-8.

Newton, A., and S.M. Mudge. 2003. Temperature and salinity regimes in a shallow mesotidal lagoon the Ria Formosa Portugal. Estuarine Coastal and Shelf Science 57 (1-2): 73-85.

Özbek, M., C. Kocak, and D. Acarli. 2012. Reproductive biology of the Mediterranean green crab Carcinus aestuarii Nardo 1847 (Crustacea Brachyura Portunidae) in Homa Lagoon Aegean Sea Turkey. Oceanological and Hydrobiological Studies International Journal of Oceanography and Hidrobiology 41: 77-80.

Pearson, K. 1901. On lines and planes of closest fit to systems of points in space. Philosophical Magazine 2: 559-572.

Perez-Miguel, M., P. Drake, and J.A. Cuesta. 2020. Temperature effect on the African pea crab Afropinnotheres monodi: Embryonic and larval developments fecundity and adult survival. Journal of Experimental Marine Biology and Ecology 527: 151380. https:// doi.org/10.1016/j.jembe.2020.151380.

Pickering, T.R., L.A. Poirier, T.J. Barrett, S. McKenna, J. Davidson, and P.A. Quijón. 2017. Non-indigenous predators threaten ecosystem engineers: Interactive effects of green crab and oyster size on American oyster mortality. Marine Environmental Research 127: 24-31. https://doi.org/10.1016/j.marenvres.2017.03.002.

Pinheiro, M.A.A., and A. Fransozo. 1995. Fecundidade de Pachycheles haigae Rodrigues da Costa, 1960 (Crustacea Anomura Porcellanidae) em Ubatuba (SP) Brasil. Revista Brasileira De Biologia 55: 623-631.

Pinheiro, M.A.A., M.D. Baveloni, and O.S.L. Terceiro. 2003. Fecundity of the mangrove crab Ucides cordatus (Linnaues 1763) (Brachyura Ocypodidae). Invertebrate Reproduction \& Development 43: 19-26.

Quinn, T.P., T.R. Seamons, L.A. Vøllestad, and E. Duffy. 2011. Effects of Growth and Reproductive History on the Egg Size-Fecundity Tradeoff in Steelhead. Transactions of the American Fisheries Society 140 (1): 45-51. https://doi.org/10.1080/00028487.2010.550244.

Reid, D.G., and E. Naylor. 1994. Size-related mating success in the shore crab. Journal of Zoology 232: 397-401.

Rewitz, K., B. Styrishave, M.H. Depledge, and O. Andersen. 2004. Spatial and temporal distribution of shore crabs Carcinus maenas in a small tidal estuary (Looe estuary Corwall England). Journal of Crustacean Biology 24: 178-187. https://doi.org/10. $1651 / \mathrm{C}-2417$. 
Ribeiro, J., C.C. Monteiro, P. Monteiro, L. Bentes, R. Coelho, J.M.S. Gonçalves, P.G. Lino, and K. Erzini. 2008. Long-term changes in fish communities of the Ria Formosa coastal lagoon (southern Portugal) based on two studies made 20 years apart. Estuarine Coastal Shelf Science 76: 57-68.

Rodríguez-Félix, D., M.Á. Cisneros-Mata, D. Guevara-Aguirre, E.A. Aragón-Noriega, and E. Alcántara-Razo. 2018. Variability in fecundity of the brown crab Callinectes bellicosus Stimpson 1859 (Brachyura Portunidae), along the coast of Sonora. Crustaceana 91 (12): 1523-1536.

Shephard, S., S.P.R. Greenstreet, G.J. Piet, A. Rindorf, and M. DickeyCollas. 2015. Surveillance indicators and their use in implementation of the Marine Strategy Framework Directive. ICES Journal of Marine Science 72 (8): 2269-2277. https://doi.org/10.1093/ icesjms/fsv131.

Smith, R.J. 2009. Use and misuse of reduced major axis for line-ftting. American Journal of Physical Anthropology 140: 476-486. https://doi.org/10.1002/ajpa.21090.

Spitzner, F., L. Giménez, R. Meth, S. Harzsch, and G. Torres G. 2019. Unmasking intraspecific variation in offspring responses to multiple environmental drivers. Marine Biology 166: 112. https://doi. org/10.1007/s00227-019-3560-y.

Sousa, A.I., J.F. Silva, A. Azevedo, and A.I. Lillebø. 2019. Blue Carbon stock in Zostera noltei meadows at Ria de Aveiro coastal lagoon (Portugal) over a decade. Scientific Reports 9: 14387.

Sprung, M. 2001. Larval abundance and recruitment of Carcinus maenas $L$. close to its southern geographic limit: a case of match and mismatch. Hydrobiologia 449 (1/3): 153-158. https://doi.org/10. 1023/a:1017565708910.

Thresher, R.E., M. Werner, J.T. Høeg, I. Svane, H. Glenner, N.E. Murphy, and C. Wittwer. 2000. Developing the options for managing marine pests: Specificity trials on the parasitic castrator Sacculina carcini against the European crab Carcinus maenas and related species. Journal of Experimental Marine Biology and Ecology 254: 37-51. https://doi.org/10.1016/s0022-0981(00)00260-4.

Tiraşin, E.M., M. Salman, M. Akalin, and O. Özaydin. 2020. Population dynamics of the mediterranean green crab Carcinus aestuarii nardo 1847 (Crustacea: Portunidae) in the gediz delta (İzmir Bay
Eastern Aegean Sea). Acta Adriatica 61 (1): 39-56. https://doi. org/10.32582/aa.61.1.3.

Vermeiren, P., and M. Sheaves. 2014. Predicting habitat associations of five intertidal crab species among estuaries. Estuarine Coastal and Shelf Science 149: 133-142.

Vernberg, F.J., and S. Piyatiratitivorakul. 1998. Effects of salinity and temperature on the bioenergetics of adult stages of the grass shrimp (Palaemonetes pugio Holthuis) from the north inlet estuary South Carolina. Estuaries 21: 176-193.

Vieira, V.M.N.C.S., and J. Creed. 2013a. Estimating significances of differences between slopes: A new methodology and software. Computational Ecology and Software 3 (3): 44-52.

Vieira, V.M.N.C.S., and J. Creed. 2013b. Significances of differences between slopes: An upgrade for replicated time series. Computational Ecology and Software 3 (4): 102-109.

Vieira, V.M.N.C.S., J. Creed, R.A. Scrosati, A. Santos, G. Dutschke, F. Leitão, A.H. Engelen, O.R. Huanel, M.-L. Guillemin, M. Mateus, and R. Neves. 2016. On the choice of linear regression algorithms. Annual Research \& Review in Biology 10 (3): 1-9. https://doi.org/ 10.9734/arrb/2016/25219.

Vieira, V.M.N.C.S., I.E. Lopes, and J.C. Creed. 2018. The biomassdensity relationship in seagrasses and its use as an ecological indicator. BMC Ecology 18: 44. https://doi.org/10.1186/ s12898-018-0200-1

Waser, A.M., R. Dekker, J.I. Witte, N. McSweeney, B.J. Ens, and J. van der Meer. 2017. Quantifying Tidal Movements of the Shore Crab Carcinus maenas on to Complex Epibenthic Bivalve Habitats. Estuaries and Coasts 41 (2): 507-520. https://doi.org/10. 1007/s12237-017-0297-z.

Young, A.M., and J.A. Elliott. 2020. Life History and Population Dynamics of Green Crabs (Carcinus maenas). Fishes 5 (1): 4-44. https://doi.org/10.3390/fishes5010004.

Young, A.M., J.A. Elliott, J.M. Incatasciato, and M.L. Taylor. 2017. Seasonal catch size color and assessment of trapping variables for the European green crab Carcinus maenas (Linnaeus 1758) (Brachyura: Portunoidea: Carcinidae) a nonindigenous species in Massachusetts, USA. Journal of Crustacean Biology 37 (5): 556-570. https://doi.org/10.1093/jcbiol/rux068. 